\title{
Electrodeposition of copper (II) sulfide and zinc sulfide onto polycrystalline gold electrode
}

\section{Bakır (II) sülfü̈r ve çinko sülfürrün polikristalin allın elektrot üzerine elektrodepozisyonu}

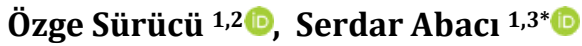 \\ ${ }^{1}$ Department of Chemistry, Faculty of Science, Hacettepe University, Ankara, TURKEY \\ ${ }^{2}$ Department of Chemistry, Faculty of Science, Ege University, Izmir, TURKEY \\ ${ }^{3}$ Advanced Technologies Application and Research Center, Hacettepe University, Ankara, TURKEY \\ Sorumlu Yazar / Corresponding Author*: sabaci@hacettepe.edu.tr \\ Geliş Tarihi / Received: 20.01.2020 \\ Kabul Tarihi / Accepted: 07.06.2020 \\ Araștırma Makalesi/Research Article \\ DEUFMD 22(66), 769-779.
}

\section{Abstract}

An electrodeposition-based process was developed in this work. Electrochemical atomic layer epitaxy (ECALE) and co-deposition methodologies were employed to grow copper (II) sulfide (CuS) and zinc sulfide (ZnS) thin films as photovoltaic semiconductors on polycrystalline gold electrode. The deposition potentials of copper $(\mathrm{Cu})$, zinc $(\mathrm{Zn})$ and sulfur $(\mathrm{S})$ were defined separately by cyclic voltammetry. Thin films were created from an electrolyte containing copper (II) sulfate $\left(\mathrm{CuSO}_{4}\right)$, sodium sulfur $\left(\mathrm{Na}_{2} \mathrm{~S}\right)$ and zinc sulfate $\left(\mathrm{ZnSO}_{4}\right)$ in ethylenediaminetetraacetic acid (EDTA) using both cyclic voltammetry and bulk electrolysis techniques. The influence of bath temperature at the deposition potential was studied to determine the crystallinity of deposits. From the chronoamperometry results including the transients obtained within the under potential region, the nucleation and growth process of deposits were estimated. In this way, an electrodeposition-based method for $\mathrm{CuS}$ and $\mathrm{ZnS}$ semiconductors in a comparable basis was improved on polycrystalline gold substrate.

Keywords: Copper, Zinc, Underpotential deposition, Co-deposition, ECALE.

Öz

$\mathrm{Bu}$ çalışmada, elektrodepozisyona dayanan bir sistem geliştirilmiștir. Elektrokimyasal atomik tabaka epitaksi (ECALE) ve ko-depozisyon metodolojileri, bakır (II) sülfür (CuS) ve çinko sülfür (CuS) ince filmlerinin polikristalin altın elektrot üzerinde fotovoltaik yarı-iletkenler olarak büyütülmesi için kullanılmıştır. Bakır (Cu), çinko $(\mathrm{Zn})$ ve kükürdün $(\mathrm{S})$ biriktirme potansiyelleri dönüşümlü voltametri ile ayrı ayrı belirlenmiştir. İnce filmler etilendiamin tetra asetik asit (EDTA) içinde bakır (II) sülfat $\left(\mathrm{CuSO}_{4}\right)$, sodyum sülfür $\left(\mathrm{Na}_{2} \mathrm{~S}\right)$ ve çinko sülfat $\left(\mathrm{ZnSO}_{4}\right)$ içeren bir elektrolit çözeltisinden hem dönüşümlü voltametri hem de bulk elektroliz teknikleri kullanılarak olușturulmuștur. Biriktirme potansiyelindeki sıcaklık etkisi katmanların kristalliğinin belirlenmesi için çalışılmıştır. Potansiyel altı alan içerisinde elde edilen geçişleri kapsayan kronoamperometri sonuçlarından, katmanların çekirdekleşme ve büyüme süreçleri değerlendirilmiştir. Böylece, $\mathrm{CuS}$ ve $\mathrm{ZnS}$ yarı iletkenleri için karşılaştırma esaslı elektrodepozisyona dayanan bir metot polikristalin altın substratta geliştirilmiştir.

Anahtar Kelimeler: Bakır, Çinko, Potansiyel altı depozisyonu, Ko-deposizyon, ECALE. 


\section{Introduction}

The underpotential deposition (UPD) of metals enables specially controlled modifications on the catalyst surface, so it has been extensively studied in electronic industry as a well-known phenomenon [1]. Such a process is applied by the interactions between ad-atoms and substrate (SS) depositing a metal (M) at a potential more positive than the Nernst potential for the couple $\mathrm{M} / \mathrm{M}^{\mathrm{n}+}[2]$.

Electrochemical atomic layer epitaxy (ECALE) is one of the UPD-based electrochemical deposition methods and it works with the sequential and separate UPD of different elements [3]. As a pioneer of UPD-based electrochemical techniques, ECALE has been widely applied for the electrochemical growth of well-ordered semiconductor materials [4]. In another UPD-based electrochemical technique, UPD-based co-deposition has focused on the electrodeposition of a compound from the same solution at a common UPD potential [5]. Such a practical and applicable method can be successfully used in the production of nanostructured semiconductors [6].

The mainly used substrates are gold ( $\mathrm{Au}$ ) [7], platinum (Pt) [8], silver $(\mathrm{Ag})[9]$ and copper $(\mathrm{Cu})$ $[10]$ in the form of single and polycrystalline for photovoltaic applications. Most of the applications are aimed at chalcogenide compounds such as cadmium telluride (CdTe) and copper indium selenide (CuInSe 2$)$ containing tellurium (Te), indium (In) and selenium (Se) as anode material, but sulfides of $\mathrm{Cu}$ and zinc $(\mathrm{Zn})$ has been worked out less [11]. Electrodeposition of $\mathrm{Zn}$ on metals are widely used on industrial scale as corrosion protective coatings, but the electrochemical process of zinc in various electrolytes is not well-known [12]. Initial studies about $\mathrm{Zn}$ electrodeposition have focused on overvoltage, $\mathrm{Zn}$ salts, bath temperature, current densities and additives [8]. A little attention has been given for the nucleation kinetics and characterization of $\mathrm{Zn}$ deposition on polycrystalline electrodes [13]

The UPD of sulfur (S) is one of the most intensively investigated topic of semiconductor family. A great deal of attention has focused on understanding the kinetics of $S$ monolayer deposition [14]. Zinc sulfide (ZnS) is among the most attractive II-VI compound semiconductors for photovoltaic applications [15]. Nevertheless copper (II) sulfide (CuS) systems are particularly interesting as active material for solar energy conversion, sensors, photocatalysis and light emitting devices, but these systems exist of different stoichiometry and crystal structure in very limited solid solutions [16]. Therefore, additional insight into the voltammetric behaviors of $\mathrm{ZnS}$ and $\mathrm{CuS}$ in the UPD range is necessary to understand the semiconducting properties of coated surfaces. Most of the studies in literature focus on one technique as ECALE or co-deposition. The choice of best nucletion and growth mechanism must be offered in literature. Also, the superiority of polycrystalline surfaces will help semiconductor industry as an easy accessible materials.

In the present paper, the electrodepositions of $\mathrm{Cu}$ and $\mathrm{Zn}$ in conjunction with $\mathrm{S}$ onto polycrystalline gold electrode were reported using a variety of methodologies such as codeposition and ECALE. Bulk electrolysis and cyclic voltammetry techniques were performed to obtain key parameters such as the deposition potential, the number of cycles, the deposition time and the effect of temperature. At the same time, chronoamperometry technique was used to determine the growth mechanism and the main structural characteristics of the deposited thin films. Single crystal surfaces needed complex systems to accumulate metals, so main point of this study was fundamentally targeted at more simple polycrystalline surfaces. At the same time, binary systems and thin films were created by the proposed dual approach.

\section{Material and Method}

\subsection{Materials}

Before starting the analysis, gold electrode was mechanically polished with 0.05 and $1.00 \mu \mathrm{m}$ superfine alumina $\left(\mathrm{Al}_{2} \mathrm{O}_{3}\right)$ powders and then cleaned electrochemically with successive cycling in $1.00 \mathrm{M}$ sulfuric acid $\left(\mathrm{H}_{2} \mathrm{SO}_{4}\right)$ solution from Sigma-Aldrich between $-0.20 \mathrm{~V}$ and +1.50 $\mathrm{V}$ until a steady state current was obtained. 0.01 $\mathrm{M}$ ethylenediaminetetraacetic acid (EDTA) $\left(\mathrm{C}_{10} \mathrm{H}_{14} \mathrm{~N}_{2} \mathrm{Na}_{2} \mathrm{O}_{8} .2 \mathrm{H}_{2} \mathrm{O}\right)$ from Merck at pH 3.00 was used as a supporting electrolyte with copper (II) sulfate $\left(\mathrm{CuSO}_{4}\right)$, sodium sulfide $\left(\mathrm{Na}_{2} \mathrm{~S}\right)$ and zinc sulfate $\left(\mathrm{ZnSO}_{4}\right)$ from Sigma-Aldrich prepared in the concentration amount of $0.01 \mathrm{M}$. EDTA was used as a complexing agent to coordinate with $\mathrm{Cu}$ and $\mathrm{Zn}$. All the other reagents were in analytical grade. At the beginning of 
analysis, pure nitrogen $\left(\mathrm{N}_{2}\right)$ gas was passed from all of the prepared solutions for sufficient period of time to extract oxygen $\left(\mathrm{O}_{2}\right)$.

\subsection{Instruments}

Bulk electrolysis and cyclic voltammetry techniques were performed on $\mathrm{CH}$ Instruments CHI660C model potentiostat with a three electrode system consisting of foil coated Pt wire as a counter electrode to reduce polarization, silver/silver chloride $(\mathrm{Ag} / \mathrm{AgCl})$ as a reference electrode and $\mathrm{Au}$ electrode with $0.031 \mathrm{~cm}^{2}$ area as a working electrode. Bulk electrolysis of $\mathrm{Cu}$ was done at $+0.550 \mathrm{~V}$ for 7 minutes, $\mathrm{S}$ at -0.520 for 10 minutes, $\mathrm{Zn}$ at $-0.750 \mathrm{~V}$ for $\mathrm{Zn}$ for 3 minutes. Cyclic voltammetry was applied between $+1.500 \mathrm{~V}$ and -1.600 for both $\mathrm{Cu}$ and $\mathrm{Zn}$. Chronoamperometry technique was performed between $-0.050 \mathrm{~V}$ and $-0.445 \mathrm{~V}$ for $\mathrm{Cu}+0.750 \mathrm{~V}$ and $+0.100 \mathrm{~V}$ for $\mathrm{Zn}$.

\subsection{Mechanism of co-deposition and ECALE of CuS and ZnS}

In the mechanism of co-deposition, EDTA which is suspended in the electrolyte works as the second phase particles and adsorbs the positively charged metal ions $\left(\mathrm{Cu}^{2+}\right.$ and $\left.\mathrm{Zn}^{2+}\right)$. The metal ions surround the EDTA particles and the resulting complexes (CuEDTA ${ }^{2-}$ and ZnEDTA $^{2-}$ ) arrive at the cathode taking action by the electrostatic attraction and the electrolyte convection. The remaining particles at the cathode surface discharge, and the three related interfacial energies including particleelectrolyte, particle-cathode and cathodeelectrolyte keep the particles on the surface by the bonding force. The metal ions are deposited on the cathode surface around the particles mixing into the metallic deposits. In the case of $\mathrm{S}$, anodic deposition is obtained on the anode surface.

Each element shows different UPD chemistry and it must be investigated to create its proper ECALE cycle. One stoichiometric layer of the proposed element is deposited in each cycle of a pure element, or a 1:1 compound. $\mathrm{CuS}$ or $\mathrm{ZnS}$ cycle is composed of several steps: initially a reductive UPD of $\mathrm{Cu}$ or $\mathrm{Zn}$ from a $\mathrm{Cu}$ or $\mathrm{Zn}$ cation solution, then oxidative UPD of $\mathrm{S}$ from a sulfide anion $\left(\mathrm{S}^{2-}\right)$ solution, and finally a second reductive UPD of $\mathrm{Cu}$ or $\mathrm{Zn}$ from a $\mathrm{Cu}$ or $\mathrm{Zn}$ cation solution. Separate solutions are used for each material and different potentials for each cycle step. The use of separate solutions and potentials gain advantage from extensive control over deposit growth, composition, and morphology. The cycle is repeated to form a thin film because the deposit thickness is a linear function of the number of cycles. Such a linear relation is a good indication of a layer by layer mechanism, and an atomic layer deposition process.

\section{Results}

\subsection{UPD of $\mathrm{Cu}, \mathrm{S}$ and $\mathrm{Zn}$}

Up to now, various electrochemical and surface characterization techniques have been used to estimate the mechanism of UPD. Among these techniques, cyclic voltammetry is extensively applied to distinguish the difference between the peak potentials of monolayer formation and bulk deposition. The first monolayer is formed from the described current peak at the potential $E>$ $E_{\text {rev }}$ while the bulk deposition occurs at $E<E_{\text {rev }}$ where $E_{\text {rev }}$ defines the Nernstian equilibrium potential [17]. Nernstian potential of $\mathrm{Cu} / \mathrm{Cu}^{2+}$ is acquired at $+0.28 \mathrm{~V}, \mathrm{Zn} / \mathrm{Zn}^{2+}$ at $-0.82 \mathrm{~V}$. In Figure $1 \mathrm{~A}$, cyclic voltammogram of $\mathrm{Au}$ electrode in EDTA containing $\mathrm{CuSO}_{4}$ (b) was compared with bare Au electrode behavior in EDTA (a), and bulk potential of $\mathrm{Cu}$ was obtained at $-0.50 \mathrm{~V}$ (less than $+0.28 \mathrm{~V}$ ) while UPD potential was obtained at $+0.55 \mathrm{~V}$ (more than $+0.28 \mathrm{~V}$ ) [18]. In Figure 1C, cyclic voltammogram of Au electrode in EDTA containing $\mathrm{ZnSO}_{4}$ (b) was matched by bare $\mathrm{Au}$ electrode behavior in EDTA (a), and bulk potential of $\mathrm{Zn}$ was observed at $-1.30 \mathrm{~V}$ (less than $-0.82 \mathrm{~V}$ ) during UPD potential was observed at $-0.75 \mathrm{~V}$ (more than $-0.82 \mathrm{~V}$ ) [19]. In the case of $\mathrm{S}$, cyclic voltammogram of $\mathrm{Au}$ electrode in EDTA containing $\mathrm{Na}_{2} \mathrm{~S}$ (b) was evaluated along with bare Au electrode behavior in EDTA (a), but anodic potentials were estimated instead of cathodic potentials (Fig. 1B). The bulk potential of $S$ was displayed at $-1.00 \mathrm{~V}$ as UPD potential was displayed at -0.52 $\mathrm{V}$, and similar UPD results to literature were reported [20]. 
DEÜ FMD 22(66), 769-779, 2020

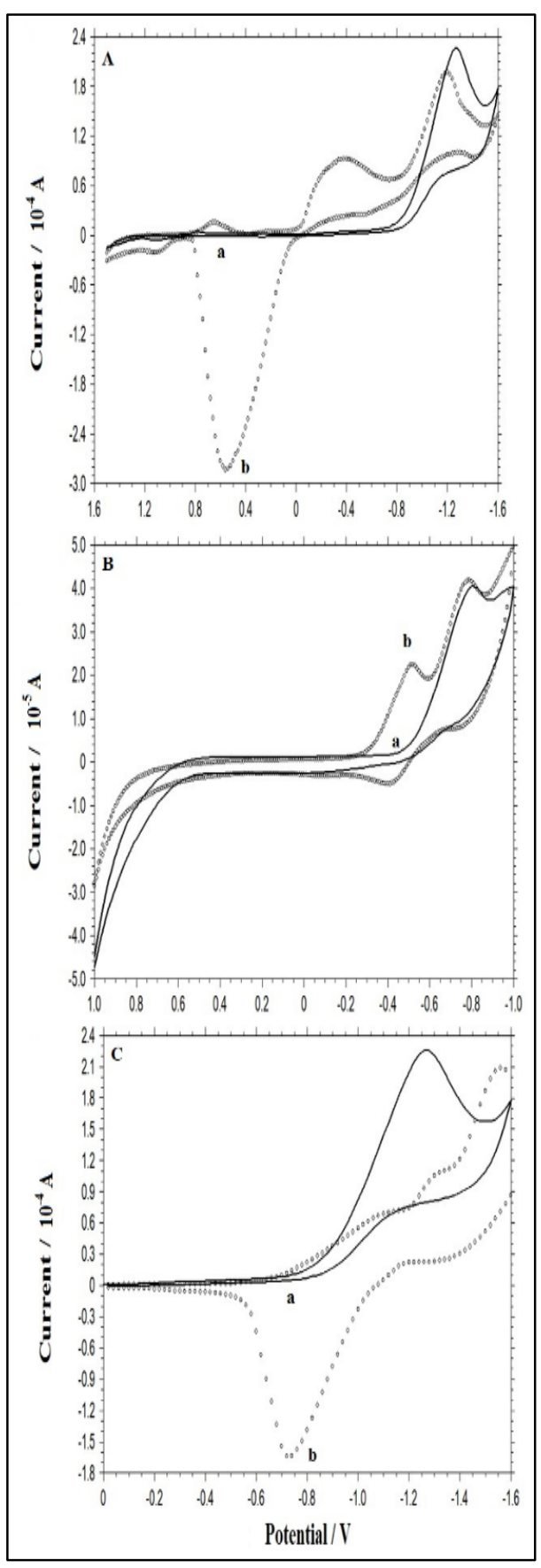

Figure 1. Cyclic voltammograms of A) bare $\mathrm{Au}$ (a) and $\mathrm{Au}$ in $\mathrm{CuSO}_{4}$ (b) between $+1.50 \mathrm{~V}$ and $-1.60, \mathrm{~B})$ bare $\mathrm{Au}(\mathrm{a})$ and $\mathrm{Au}$ in $\mathrm{Na}_{2} \mathrm{~S}(\mathrm{~b})$ between $+1.00 \mathrm{~V}$ and $-1.00 \mathrm{~V}, \mathrm{C}$ ) bare $\mathrm{Au}(\mathrm{a})$ and $\mathrm{Au}$ in $\mathrm{ZnSO}_{4}$ (b) between $0.00 \mathrm{~V}$ and $-1.60 \mathrm{~V}$ at a scan rate of $100 \mathrm{mV} \mathrm{s}^{-1}$.

\subsection{Bulk electrolysis vs. cyclic voltammetry of $\mathrm{CuS}$ and $\mathrm{ZnS}$}

The basic UPD cycle can be repeated several times to obtain thicker deposits and such a choice can be made using various electrochemical techniques such as bulk electrolysis and cyclic voltammetry [21]. In the bulk electrolysis, an evaluation between the electrolysis time and the current density response of $\mathrm{Au}$ electrode in EDTA containing both $\mathrm{CuSO}_{4}$ and $\mathrm{ZnSO}_{4}$ were given in Table 1, and the maximum current density responses were gained on $7 \mathrm{~min}$ for $\mathrm{Cu}$ and $3 \mathrm{~min}$ for $\mathrm{Zn}$ (bold marked). Therefore, bulk electrolysis was performed at that time interval.

Table 1. The electrolysis time $(t)$ vs. current density $(j)$.

\begin{tabular}{ccc}
\hline$t(\mathrm{~min})$ & $j \mathrm{cu}\left(\mathrm{A} \mathrm{m}^{-2}\right)$ & $j_{Z n}\left(\mathrm{~A} \mathrm{~m}^{-2}\right)$ \\
\hline 1 & -1.27 & -0.96 \\
3 & -3.82 & $\mathbf{- 7 . 6 4}$ \\
5 & -5.73 & -2.87 \\
7 & $\mathbf{- 1 1 . 4 6}$ & -2.23 \\
10 & -0.64 & -1.59 \\
\hline
\end{tabular}

In the case of cyclic voltammetry, a comparison between the number of cycles of depositions and the current density ( $j$ ) response of Au electrode in EDTA containing both $\mathrm{CuSO}_{4}$ and $\mathrm{ZnSO}_{4}$ were given in Table 2 , and the maximum current density responses were taken in 7 cycles and 3 cycles for $\mathrm{Cu}$ and $\mathrm{Zn}$ (bold marked), respectively. Increasing current density resulted in increasing diffusion suggesting the denser, more compact flake structure [22]. Therefore, cyclic voltammetry technique was carried out in that cycle range. 
DEÜ FMD 22(66), 769-779, 2020

Table 2. The number of cycles of depositions (\#) vs. current density (j).

\begin{tabular}{ccc}
\hline \# cycles & $j_{\mathrm{cu}}\left(\mathrm{A} \mathrm{m}^{-2}\right)$ & $j_{\mathrm{Zn}}\left(\mathrm{A} \mathrm{m}^{-2}\right)$ \\
\hline 1 & -33.44 & -1.27 \\
3 & -41.40 & $\mathbf{- 7 . 9 6}$ \\
5 & -25.48 & -4.14 \\
7 & $-\mathbf{4 7 . 7 7}$ & -2.87 \\
10 & -31.85 & -3.18 \\
\hline
\end{tabular}

Bulk electrolysis of Cu was applied at $+0.55 \mathrm{~V}$ for 7 min while cyclic voltammetry was applied at a potential range of $+0.80 \mathrm{~V}$ and $-1.60 \mathrm{~V}$ for 7 cycles. On the other side, bulk electrolysis of $\mathrm{Zn}$ was performed at $-0.75 \mathrm{~V}$ for 3 min while cyclic voltammetry was performed between $+1.50 \mathrm{~V}$ and $-1.60 \mathrm{~V}$ for 3 cycles. The methodological difference in the voltammetric behavior of $\mathrm{Au}$ electrode in EDTA containing $\mathrm{CuSO}_{4}$ and $\mathrm{Na}_{2} \mathrm{~S}$ (Figure 2A), and containing $\mathrm{Na}_{2} \mathrm{~S}$ and $\mathrm{ZnSO}_{4}$ (Figure 2B) was determined. No distinct peak difference was discovered for $\mathrm{Cu}$ in both techniques, but the UPD peak of $\mathrm{Zn}$ was lost in the event of bulk electrolysis. Therefore, the layer formation was accomplished by cyclic voltammetry.

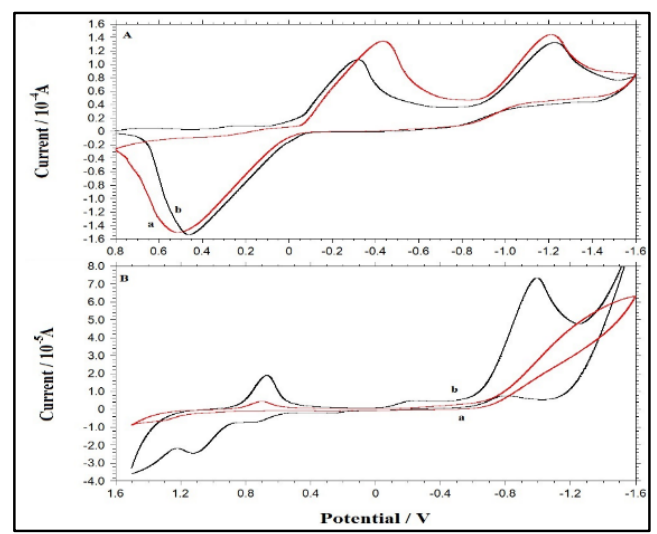

Figure 2. Cyclic voltammograms of A) bulk electrolyzed (a) and deposited $\mathrm{Au}$ (b) in $\mathrm{CuSO}_{4}$ and $\mathrm{Na}_{2} \mathrm{~S}$ between $+0.80 \mathrm{~V}$ and $-1.60 \mathrm{~V}$, and $\mathrm{B}$ ) bulk electrolyzed (a) and deposited $\mathrm{Au}$ (b) in $\mathrm{Na}_{2} \mathrm{~S}$ and $\mathrm{ZnSO}_{4}$ between $+1.50 \mathrm{~V}$ and $-1.60 \mathrm{~V}$ at a scan rate of $100 \mathrm{mV} \mathrm{s}^{-1}$.

\subsection{Co-deposition vs. ECALE of CuS and ZnS}

Cyclic voltammetric responses of Au electrode using co-deposition method based on the deposition from the same solution of the target compound at a constant UPD potential, and using ECALE method based on the deposition of each element from their separate solutions at the UPD potential of each element were represented in Figure 3. In ECALE behavior of $\mathrm{S}$ over $\mathrm{Cu}$ modified $\mathrm{Au}$ electrode (b), the main UPD peaks of $\mathrm{Cu}(+0.55 \mathrm{~V})$ and $\mathrm{S}(-0.52 \mathrm{~V})$ disappeared, but in both co-deposition (a) and ECALE behavior of $\mathrm{Cu}$ over S modified Au electrode (c), both of the $\mathrm{Cu}$ and S UPD peaks were observed. A sharper result of $\mathrm{Cu}$ over $\mathrm{S}$ modified Au electrode than codeposition technique presenting the layer formation of CuS by ECALE (Figure 3A). In the mechanism of $\mathrm{CuS}$ electrodeposition, $\mathrm{Cu}$ reduction $\left(\mathrm{Cu}^{2+}+2 \mathrm{e}^{-}=\mathrm{Cu} U \mathrm{UPD}\right)$ and $\mathrm{S}$ oxidation $\left(\mathrm{S}^{2-}\right.$ $=\mathrm{S}_{\mathrm{UPD}}+2 \mathrm{e}^{-}$) occured as 1:1. An atomic layer of $\mathrm{S}$ was deposited on one layer of $\mathrm{Cu}$, and one layer of $\mathrm{Cu}$ was deposited on one layer of $\mathrm{S}$.

In the condition of $\mathrm{Zn}$ and $\mathrm{S}$ co-deposition (a), the most obvious UPD potential of Zn $(-0.75 \mathrm{~V})$ was obtained, but in both ECALE results $\mathrm{S}$ over $\mathrm{Zn}$ modified Au electrode (b) and Zn over S modified $\mathrm{Au}$ electrode (c), the broader UPD peaks of $\mathrm{Zn}$ were monitored. For the actual S UPD $(-0.52 \mathrm{~V})$, all surfaces shifted more positive potential $(-0.25 \mathrm{~V})$. According to these results, $\mathrm{ZnS}$ layer was created using co-deposition technique from the same solutions of $\mathrm{Zn}$ and $\mathrm{S}$. In the mechanism of $\mathrm{ZnS}$ electrodeposition, $\mathrm{Zn}$ reduction $\left(\mathrm{Zn}^{2+}+2 \mathrm{e}^{-}\right.$ $=\mathrm{Zn}_{\text {UPD }}$ ) and S oxidation ( $\left.\mathrm{S}^{2-}=\mathrm{S}_{\mathrm{UPD}}+2 \mathrm{e}^{-}\right)$occured as 1:1. An atomic layer of $S$ was deposited on one layer of $\mathrm{Zn}$, and one layer of $\mathrm{Zn}$ was deposited on one layer of $\mathrm{S}$. 


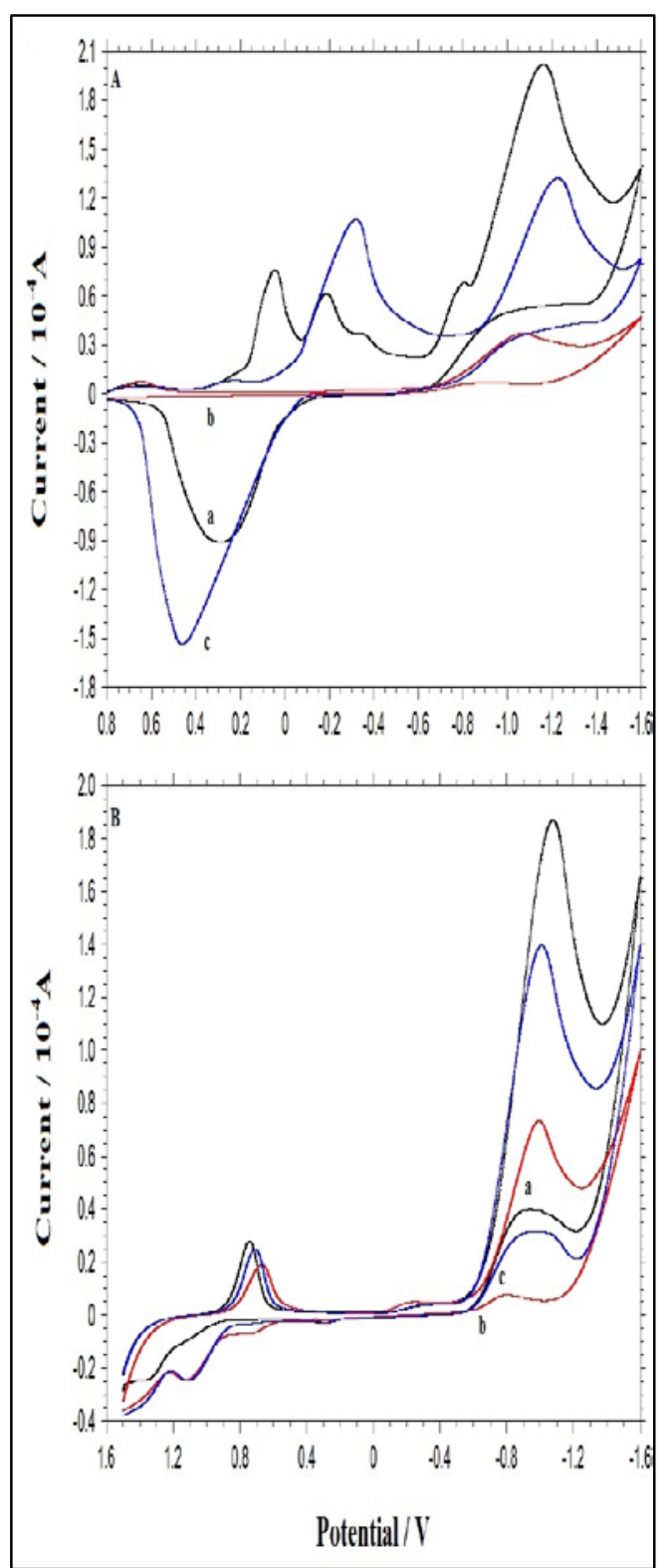

Figure 3. Cyclic voltammograms of A) Au using

(a) $\mathrm{Cu}$ and $\mathrm{S}$ by co-deposition, (b) $\mathrm{S}$ over $\mathrm{Cu}$ by ECALE, (c) Cu over $\mathrm{S}$ by ECALE techniques

between $+0.80 \mathrm{~V}$ and $-1.60 \mathrm{~V}$, and B) Au using (a) Zn and $\mathrm{S}$ by co-deposition, (b) S over Zn by ECALE, (c) Zn over $S$ by ECALE techniques between $+1.50 \mathrm{~V}$ and $-1.60 \mathrm{~V}$ at a scan rate of $100 \mathrm{mV} \mathrm{s}^{-1}$
3.4. The effect of bath temperature on UPD of CuS and ZnS

The nucleation and growth mechanism of electrodeposition can be influenced from different parameters such as the depositon potential, $\mathrm{pH}$, concentration, scan rate, substrate and temperature. In the case of temperature, various effects are determined on active surface area and potential [23]. Therefore, the influence of bath temperature on thermodynamics and kinetics of nucleation and growth onto $\mathrm{Au}$ was studied, and the bath temperature was changed from $25{ }^{\circ} \mathrm{C}$ to $40{ }^{\circ} \mathrm{C}$ to examine the change of composition and microstructure of the deposits. In Figure 4 , the current intensities of bare $\mathrm{Au}$ electrode in EDTA containing $\mathrm{CdSO}_{4}(\mathrm{~A}), \mathrm{Cu}$ and $\mathrm{S}$ co-deposited $\mathrm{Au}$ electrode (B), $\mathrm{S}$ over $\mathrm{Cu}$ modified $\mathrm{Au}$ electrode (C), and $\mathrm{Cu}$ over $\mathrm{S}$ modified Au electrode (D) in EDTA containing $\mathrm{CuSO}_{4}$ and $\mathrm{Na}_{2} \mathrm{~S}$ were compared. When the bath temperature increased from $25 \stackrel{\circ}{\circ} \mathrm{C}$ to $40 \stackrel{\circ}{\circ} \mathrm{C}$ $(d \rightarrow a)$, the intensity of the peaks increased randomly for all surfaces. The maximum current response decreased at $\mathrm{Cu}$ and $\mathrm{S}$ co-deposited $\mathrm{Au}$ electrode $\left(5.00 \times 10^{-5} \mathrm{~A}\right)$ and reached its highest point $\left(3.50 \times 10^{-4} \mathrm{~A}\right)$ at $\mathrm{Cu}$ over $\mathrm{S}$ modified $\mathrm{Au}$ electrode. A gradual rise from $25^{\circ} \mathrm{C}$ to $35^{\circ} \mathrm{C}$ was observed at $\mathrm{Cu}$ over $\mathrm{S}$ modified Au electrode, but a continuos tendency of increase and decrease was obtained from A to C. Therefore, the layer formation of $\mathrm{CuS}$ was carried out using ECALE technique as in UPD results of $\mathrm{Cu}$ over $\mathrm{S}$ modified $\mathrm{Au}$ electrode, and the increase of the bath temperature improved the crystallinity of the CuS deposit [24]. 


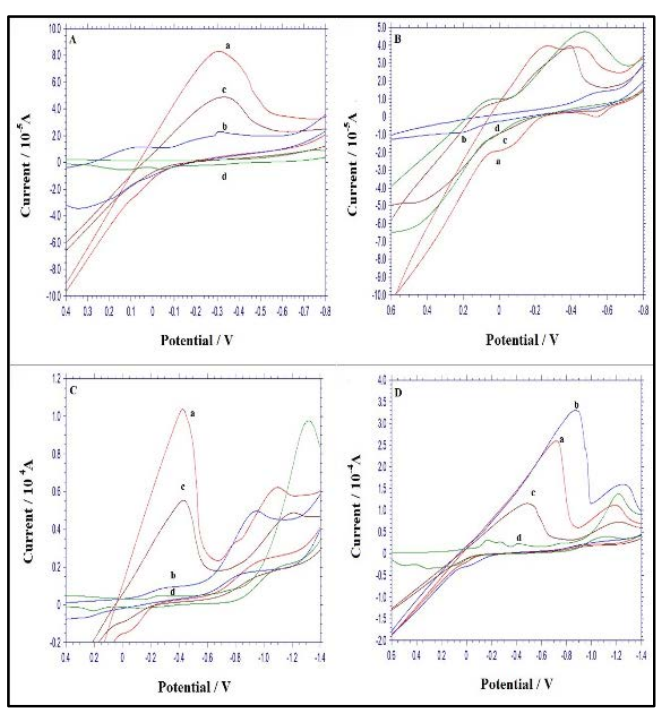

Figure 4. Cyclic voltammograms of A) bare $\mathrm{Au}$, B) $\mathrm{Au}$ using $\mathrm{Cu}$ and $\mathrm{S}$ by co-deposition, C) $\mathrm{Au}$ using $\mathrm{S}$ over $\mathrm{Cu}$ by ECALE, and D) $\mathrm{Au}$ using $\mathrm{Cu}$ over $\mathrm{S}$ by ECALE techniques between $+0.60 \mathrm{~V}$ and $-1.40 \mathrm{~V}$ at a scan rate of $100 \mathrm{mV} \mathrm{s}^{-1}$ and at a bath temperature of (a) $40{ }^{\circ} \mathrm{C}$, (b) $35^{\circ} \mathrm{C}$, (c) 30

$$
{ }^{\circ} \mathrm{C} \text {, (d) } 25 \stackrel{\circ}{\circ} \text {. }
$$

Figure 5 demonstrated the current intensity changes of bare Au electrode in EDTA containing $\mathrm{ZnSO}_{4}(\mathrm{~A}), \mathrm{Zn}$ and $\mathrm{S}$ co-deposited Au electrode (B), Zn over S modified Au electrode (C), and S over $\mathrm{Zn}$ modified $\mathrm{Au}$ electrode (D) in EDTA containing $\mathrm{ZnSO}_{4}$ and $\mathrm{Na}_{2} \mathrm{~S}$. As the bath temperature increased from $25{ }^{\circ} \mathrm{C}$ to $40{ }^{\circ} \mathrm{C}$ $(d \rightarrow a)$, the intensity of the peaks increased randomly for all surfaces. The maximum peak currents (between $2.00 \times 10^{-5} \mathrm{~A}$ and $3.00 \times 10^{-5}$ A) were almost same even though the surfaces were formed by different techniques. A progressive jump was monitored at only $\mathrm{Zn}$ and $\mathrm{S}$ co-deposited $\mathrm{Au}$ electrode, but all other surfaces showed an irregular upward trend. Therefore, the layer formation of $\mathrm{ZnS}$ was carried out using co-deposition technique as in UPD results of $\mathrm{Zn}$ and $\mathrm{S}$ co-deposited $\mathrm{Au}$ electrode, and the bath temperature had an influence on the composition of the deposited films.

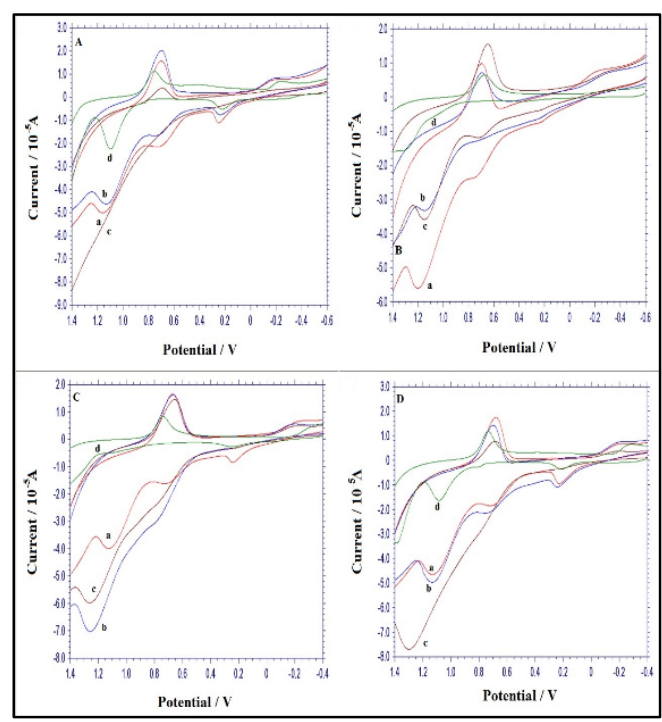

Figure 5. Cyclic voltammograms of $\mathbf{A}$ ) bare $\mathrm{Au}$, B) Au using $\mathrm{Zn}$ and $\mathrm{S}$ by co-deposition, C) $\mathrm{Au}$ using $\mathrm{Zn}$ over $\mathrm{S}$ by ECALE, and D) Au using $\mathrm{S}$ over $\mathrm{Zn}$ by ECALE techniques between $+1.40 \mathrm{~V}$ and $-0.40 \mathrm{~V}$ at a scan rate of $100 \mathrm{mV} \mathrm{s}^{-1}$ and at a bath temperature of (a) $40{ }^{\circ} \mathrm{C}$, (b) $35^{\circ} \mathrm{C}$, (c) 30 ${ }^{\circ} \mathrm{C}$, (d) $25 \stackrel{\circ}{\circ}$.

3.5. Kinetics of the electrodepositions of $\mathrm{CuS}$ and $\mathrm{ZnS}$

Copper monolayer formation onto $\mathrm{Au}$ polycrystalline electrode is independent from the crystalline nature of the Au electrode. When a copper monolayer is grown up during the UPD, a difference in the corresponding current transients occur. Potentiostatic current density transients during nucleation and growth onto $\mathrm{Au}$ vary at different potentials. Therefore, different mechanisms should be involved in each case of the monolayer formation. In a more detailed analysis of the transients, the polycrystalline $\mathrm{Au}$ electrode represents more similarities than actual differences with respect to the single crystal electrode. Current-time transients from chronoamperometry experiments are compared with the theoretical models to characterize the type of nucleation for deposits [25]. In order to describe totally the shape of the transients, the model $\left(j_{\text {total }}=j_{\mathrm{AD}}+j_{2 \mathrm{D}}\right)$ explored by Hölzle et al. is used where the overall current density for the electrodeposition process $\left(j_{\text {total }}\right)$ is the linear sum of a Langmuir-type adsorption term ( $\left.j_{\mathrm{AD}}\right)$ and a 2D nucleation process $\left(j_{2} \mathrm{D}\right)[26]$. 
In Figure 6, chronoamperometric results of bare $\mathrm{Au}$ (a) and coated Au (b) in EDTA containing $\mathrm{CuSO}_{4}$, coated $\mathrm{Au}$ using $\mathrm{Cu}$ and $\mathrm{S}$ by co-deposition (c), and coated Au using Cu over S by ECALE (d) techniques in EDTA containing $\mathrm{CuSO}_{4}$ and $\mathrm{Na}_{2} \mathrm{~S}$ were estimated. In all conditions, the current density decreased as a function of elapsing time $(t<0.03 \mathrm{~s})$, right from the start of the transient resulted in no nucleation model giving a clear description of the transient shape. For $t>0.03 \mathrm{~s}$, the shape of transient supported the formation and growth of 2D nuclei, limited by ad-atom incorporation. As it could be seen in Figure 6 $(\mathrm{a} \rightarrow \mathrm{b})$, a current decrease appeared in $\mathrm{Cu}$ monolayer formation, and a current increase was observed by $\mathrm{Cu}$ and $\mathrm{S}$ co-deposited $\mathrm{Au}$ electrode $(b \rightarrow c)$ similar to literature [26]. As a result, chronoamperometry process of $\mathrm{CuS}$ layer proceeded by a two-step mechanism involving Langmuir-type adsorption accompanied by nucleation and two dimensional growth, and $\mathrm{Cu}$ deposition was determined by the Hölzle model $\left(j_{\text {total }}=j_{\mathrm{AD}}+j_{2 \mathrm{D}}\right)$ in which the electrodeposition process $\left(j_{\text {total }}\right)$ was the linear sum of a Langmuirtype adsorption term $\left(j_{\mathrm{AD}}\right)$ and a $2 \mathrm{D}$ nucleation process ( $\left.j_{2 \mathrm{D}}\right)$.

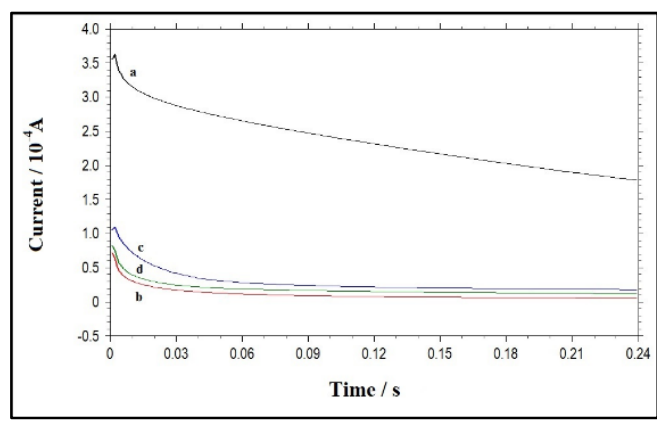

Figure 6. Chronoamperometric behaviors of a) bare $\mathrm{Au}$ in EDTA, b) $\mathrm{Au}$ in $\mathrm{CuSO}_{4}$, c) $\mathrm{Au}$ using $\mathrm{Cu}$ and $\mathrm{S}$ by co-deposition, d) $\mathrm{Au}$ using $\mathrm{Cu}$ over $\mathrm{S}$ by ECALE techniques in $\mathrm{CuSO}_{4}$ and $\mathrm{Na}_{2} \mathrm{~S}$ between

$$
-0.050 \mathrm{~V} \text { and }-0.445 \mathrm{~V} \text {. }
$$

In order to analyze the experimental data by usual procedures, the plots of $j$ vs. $t^{-1 / 2}(\mathrm{~A})$ and $j$ vs. $t^{1 / 2}$ (B) for bare Au (a) and coated Au (b) in EDTA containing $\mathrm{CuSO}_{4}$, coated $\mathrm{Au}$ for using $\mathrm{Cu}$ and $\mathrm{S}$ by co-deposition (c), and coated $\mathrm{Au}$ for using Cu over S by ECALE (d) techniques in EDTA containing $\mathrm{CuSO}_{4}$ and $\mathrm{Na}_{2} \mathrm{~S}$ recorded between $-0.050 \mathrm{~V}$ and $-0.445 \mathrm{~V}$ were given in Figure 7 .

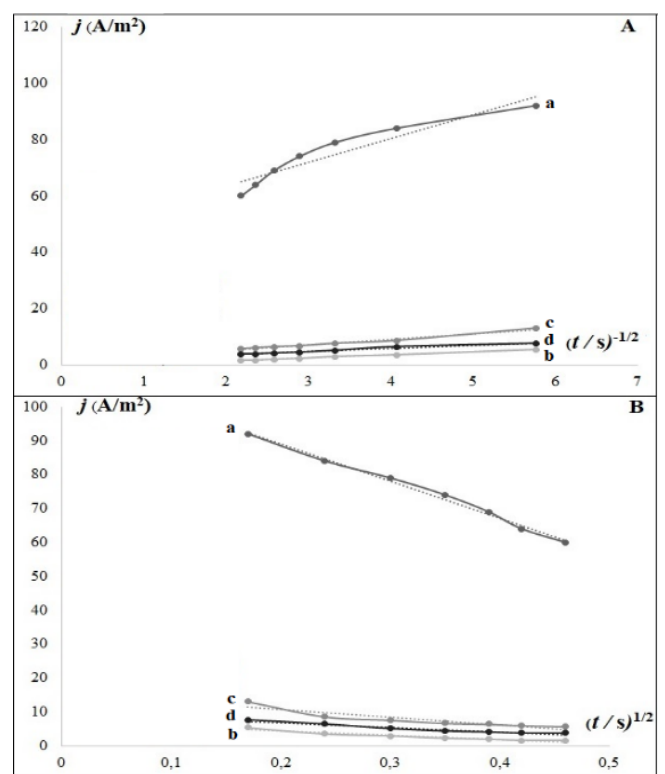

Figure 7. The plots of A) $j$ vs. $t^{-1 / 2}$ and B) $j$ vs. $t^{1 / 2}$ indicating the current transients of bare $\mathrm{Au}$ (a), $\mathrm{Au}$ in $\mathrm{CuSO}_{4}$ (b), Au using $\mathrm{Cu}$ and $\mathrm{S}$ by codeposition (c), Au using Cu over $\mathrm{S}$ by ECALE (d) techniques in $\mathrm{CuSO}_{4}$ and $\mathrm{Na}_{2} \mathrm{~S}$ recorded between $-0.050 \mathrm{~V}$ and $-0.445 \mathrm{~V}$, see in Figure 6 .

As it was seen from Table 3, the current density response of bare $\mathrm{Au}$ electrode was directly proportional to $t^{1 / 2}$ due to the metal ion behavior of Au while all other monolayered surfaces were directly proportional to $t^{-1 / 2}$. Therefore, resulting straight line from Figure $7 \mathrm{~A}(\mathrm{~b} \rightarrow \mathrm{d})$ showed $\mathrm{a}$ diffusion-controlled process according to the Cottrell equation [27] and the higher the slope of graph was obtained in Figure 7A (c) because of the current increase by $\mathrm{Cu}$ and $\mathrm{S}$ co-deposited $\mathrm{Au}$ electrode. Diffusion coefficients $(D)$ were also calculated as $1.00,3.37,1.10\left(\times 10^{-8} \mathrm{~cm}^{2} / \mathrm{s}\right)$ from $\mathrm{b}$ to $\mathrm{d}$, respectively, and the highest diffusivity was obtained at $\mathrm{Cu}$ and $\mathrm{S}$ co-deposited $\mathrm{Au}$ electrode. 
DEÜ FMD 22(66), 769-779, 2020

Table 3. Equations and R-squared values for the plots of of $j$ vs. $t^{-1 / 2}$ and $j$ vs. $t^{1 / 2}$.

\begin{tabular}{ccc}
\hline deposition & $j$ vs. $t^{1 / 2}$ & $j$ vs. $t^{1 / 2}$ \\
\hline $\mathrm{a}$ & $\mathrm{y}=8.50 \mathrm{x}+46.41$ & $\mathrm{y}=-109.5 \mathrm{x}+111.0$ \\
& $\mathrm{R}^{2}=0.90$ & $\mathrm{R}^{2}=0.99$ \\
$\mathrm{~b}$ & $\mathrm{y}=1.99 \mathrm{x}+1.12$ & $\mathrm{y}=-22.6 \mathrm{x}+15.2$ \\
& $\mathrm{R}^{2}=0.98$ & $\mathrm{R}^{2}=0.85$ \\
$\mathrm{c}$ & $\mathrm{y}=1.14 \mathrm{x}+1.25$ & $\mathrm{y}=-13.9 \mathrm{x}+9.62$ \\
& $\mathrm{R}^{2}=0.97$ & $\mathrm{R}^{2}=0.94$ \\
$\mathrm{~d}$ & $\mathrm{y}=1.08 \mathrm{x}-0.86$ & $\mathrm{y}=-12.8 \mathrm{x}+6.97$ \\
& $\mathrm{R}^{2}=0.99$ & $\mathrm{R}^{2}=0.92$ \\
\hline
\end{tabular}

Figure 8 demonstrated chronoamperometric responses of coated $\mathrm{Au}$ (a) in EDTA containing $\mathrm{ZnSO}_{4}$, coated $\mathrm{Au}$ using $\mathrm{Zn}$ and $\mathrm{S}$ by co-deposition (b), and coated Au using Zn over S by ECALE (c) techniques in EDTA containing $\mathrm{ZnSO}_{4}$ and $\mathrm{Na}_{2} \mathrm{~S}$. A current decline $(\mathrm{a} \rightarrow \mathrm{b})$ was observed by $\mathrm{Zn}$ and $\mathrm{S}$ co-deposited $\mathrm{Au}$ electrode, but when $\mathrm{Zn}$ monolayer was formed over $\mathrm{S}$ modified $\mathrm{Au}$ electrode (c), the current increased again. The general curves in the UPD range had a monotonous character approaching close to zero quickly. At later times, the current seemed to be independent on the deposition time. Such an observation was made by the Despic and Pavlovic model referred to a repetitive 2D layer growth in which smooth deposit reproduced the original surface morphology [28]. Therefore, it proceeded by a 2D nucleation and growth mechanism.

In Figure 8, inset, the plots of $j$ vs. $t^{-1 / 2}$ for coated $\mathrm{Au}$ (a) in EDTA containing $\mathrm{ZnSO}_{4}$, coated $\mathrm{Au}$ using Zn and S by co-deposition (b), and coated $\mathrm{Au}$ using $\mathrm{Zn}$ over $\mathrm{S}$ by ECALE (c) techniques in EDTA containing $\mathrm{ZnSO}_{4}$ and $\mathrm{Na}_{2} \mathrm{~S}$ recorded between $+0.75 \mathrm{~V}$ and $+0.10 \mathrm{~V}$ were indicated The resulting linearity on all surfaces showed a diffusion-controlled process according to the Cottrell equation. Diffusion coefficients were calculated as $8.43,0.28,1.65\left(\times 10^{-8} \mathrm{~cm}^{2} / \mathrm{s}\right)$ from a to $c$, respectively, and the higher diffusivity than $\mathrm{Zn}$ and $\mathrm{S}$ co-deposited $\mathrm{Au}$ electrode was obtained at $\mathrm{Zn}$ over $\mathrm{S}$ deposited Au electrode by ECALE technique. For the electrodeposition of ZnS (b and c), the diffusion coefficients $(D \sim 1 / \eta)$ based on the slopes declined normally because of the absolute viscosity $(\eta)$ which was greater for deposits in comparison with free metals (a).

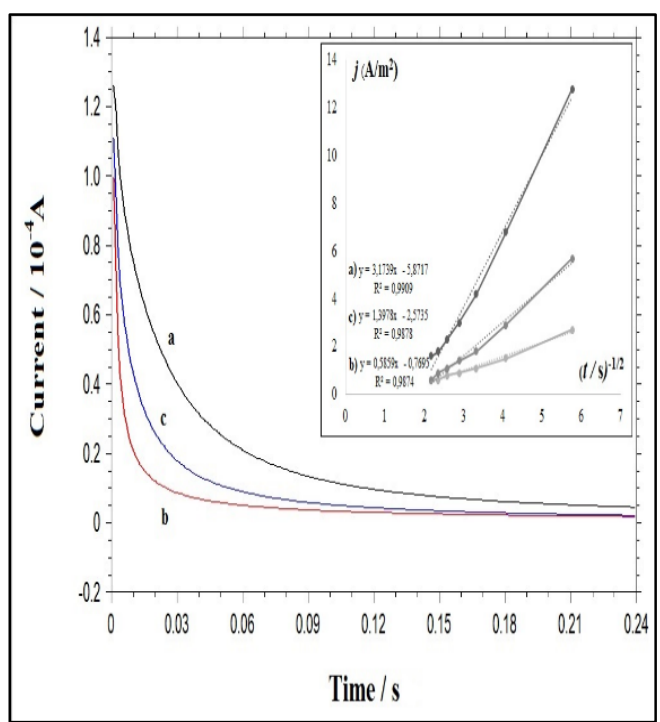

Figure 8. Chronoamperometric behaviors of a) $\mathrm{Au}$ in $\mathrm{ZnSO}_{4}$, b) $\mathrm{Au}$ using $\mathrm{Zn}$ and $\mathrm{S}$ by codeposition, c) Au using Zn over $S$ by ECALE techniques in $\mathrm{ZnSO}_{4}$ and $\mathrm{Na}_{2} \mathrm{~S}$ between $+0.75 \mathrm{~V}$ and $+0.10 \mathrm{~V}$. Inset: the plots of $j$ vs. $t^{-1 / 2}$ indicating the current transients.

\section{Discussion and Conclusion}

An easy, one-step procedure for the electrodeposition of $\mathrm{CuS}$ and $\mathrm{ZnS}$ was developed. Development of the binary system composed of co-deposition and ECALE techniques gained advantage from comparable point of view. Chosen two methods to produce semiconducting $\mathrm{CuS}$ and $\mathrm{ZnS}$ thin films were described in depth onto polycrystalline electrodes. A variety of electrochemical deposition processes such as bulk electrolysis and cyclic voltammetry were used to select the ideal deposition method. The influence of bath temperature on UPD was studied to estimate the quality and crystallinity of deposits, and almost same results with the UPD responses of $\mathrm{CuS}$ and $\mathrm{ZnS}$ were obtained in various bath temperatures. The decision on the kinetic behaviors of deposits was made by chronoamperometry technique, and two-step mechanism involving adsorption accompanied by nucleation and growth was obtained. To conclude, UPD was applied on pure metals and their deposits through the study, so that the recommended method may arouse as a model in both semiconducting industry and environmental science. 


\section{DEÜ FMD 22(66), 769-779, 2020}

\section{References}

[1] Oviedo, O.A., Reinaudi, L., Garcia, S.G., Leiva, E.P.M 2016. Underpotential deposition: from fundamentals and theory to applications at the nanoscale. Scholz F., ed. Springer International Publishing, Switzerland. DOI: 10.1007/s10008-0163222-7.

[2] Mascaro, L.H., Santos, M.C., Machado, S.A.S., Avaca L.A. 2002. Voltammetric and Rotating Ring-Disk Studies of the Influence of Anions in the Underpotential Deposition of Zinc on Platinum. Journal of the Brazilian Chemical Society, Vol. 13, p. 529-534. DOI: 10.1590/S010350532002000400019.

[3] Gregory, B.W., Stickney, J.L. 1991. Electrochemical atomic layer epitaxy (ECALE). Journal of Electroanalytical Chemistry, Vol. 300, p. 543-561. DOI: 10.1016/0022-0728(91)85415-L.

[4] Liang, X., Jayaraju, N., Thambidurai, C., Zhang, Q., Stickney, J.L. 2011. Controlled elec-trochemical formation of GexSbyTez using atomic layer deposition (ALD). Chemistry of Materials, Vol. 23, p. 1742-1752. DOI: $10.1021 / \mathrm{cm} 102672 \mathrm{j}$

[5] Öznülüer, T., Erdoğan, İ.Y., Şişman, İ., Demir, Ü. 2005. Electrochemical atom-by-atom growth of $\mathrm{PbS}$ by modified ECALE method. Chemistry of Materials, Vol. 17, p. 935-937. DOI: $10.1021 / \mathrm{cm} 048246 \mathrm{~g}$.

[6] Zhu, W., Liu, X., Liu, H., Tong, D., Yang, J., Peng, J. 2010. Coaxial heterogeneous structure of $\mathrm{TiO}_{2}$ nanotube arrays with $\mathrm{CdS}$ as a superthin coating synthesized via modified electrochemical atomic layer deposition. Journal of the American Chemical Society, Vol. 132, p. 12619-12626. DOI 10.1021/ja1025112.

[7] Noyhouzer, T., Mandler, D. 2011. Determination of low levels of cadmium ions by the under potential deposition on a self-assembled monolayer on gold electrode. Analytica Chimica Acta, Vol. 684, p. 1-7. DOI: 10.1016/j.aca.2010.10.021.

[8] Aramataa, A., Taguchi, S., Fukudaa, T., Nakamuraa, M., Horanyi, G. 1998. Underpotential deposition of zinc ions at single crystal electrodes and the effect of the adsorbed anions. Electrochimica Acta, Vol. 44, p. 999-1007. DOI: 10.1016/S0013-4686(98)00204-7.

[9] Giaccherini, A., Cinotti, S., Guerri, A., Carla, F., Montegrossi, G., Vizza, F., Lavacchi, A., Felici, R., Di Benedetto, F., Innocenti, M. 2017. Operando SXRD study of the structure and growth process of $\mathrm{Cu} 2 \mathrm{~S}$ ultra-thin films. Scientific Reports, Vol. 7, p. 1615. DOI: 10.1038/s41598-017-01717-0.

[10] Bozzini, B., Baker, M.A., Cavallotti, P.L., Cerri, E., Lenardi, C. 2000. Electrodeposition of ZnTe for Photovoltaic Cells. Thin Solid Films, Vol. 361, p. 388395. DOI: 10.1016/S0040-6090(99)00808-1.

[11] Pauporte, T., Lincot, D. 2000. Electrodeposition of semiconductors for optoelectronic devices: results on zinc oxide. Electrochimica Acta, Vol. 45, p. 3345 3353. DOI: 10.1016/S0013-4686(00)00405-9.

[12] Heo, P., Ichino, R., Okido, M. 2006. ZnTe electrodeposition from organic solvents. Electrochimica Acta, Vol. 51, p. 6325-6330. DOI: 10.1016/j.electacta.2006.04.016.
[13] Dogel, J., Freyland, W. 2003. Layer-by-layer growth of zinc during electrodeposition on $\mathrm{Au}(111)$ from a room temperature molten salt. Physical Chemistry Chemical Physics, Vol. 5, p. 2484-2487. DOI: 10.1039/B303388K.

[14] Alanyalıŏlu, M., Cakal, H., Öztürk, A.E., Demir, Ü. 2001. Electrochemical studies of the effects of $\mathrm{pH}$ and the surface structure of gold substrates on the underpotential deposition of sulfur. The Journal of Physical Chemistry B, Vol. 105, p. 10588-10593. DOI: 10.1021/jp004227s.

[15] Mahalingam, T., John, V.S., Rajendran, S., Ravi, G., Sebastian, P.J. 2002. Annealing studies of electrodeposited zinc telluride thin films. Surface and Coatings Technology, Vol. 155, p. 245-249. DOI: 10.1016/S0257-8972(02)00117-2.

[16] Short, A., Jewell, L., Bielecki, A., Keiber, T., Bridges, F., Carter, S., Alers, G. 2014. Structure in multilayer films of zinc sulfide and copper sulfide via atomic layer deposition. Journal of Vacuum Science \& Technology A, Vol. 32, p. 01A125. DOI: 10.1116/1.4847956.

[17] Sudha, V., Sangaranarayanan, M.V. 2005. Underpotential deposition of metals - Progress and prospects in modelling. Journal of Chemical Sciences, Vol. 117, p. 207-218. DOI: 10.1007/BF02709289.

[18] Chiu, Y.D., Dow, W.P., Liu, Y.F., Lee, Y.L., Yau, S.L., Huang, S.M. 2011. Copper Underpotential Deposition on Gold in the Presence of Polyethylene Glycol and Chloride. International Journal of Electrochemical Sciences, Vol. 6, p. 3416-3426.

[19] Taguchi, S., Kondo, M., Mori, H., Aramata, A. 2013. Formation of zinc-oxianion complex adlayer by underpotential deposition of $\mathrm{Zn}$ on $\mathrm{Au}\left(\begin{array}{lll}1 & 1 & 1\end{array}\right)$ electrode: Preferential formation of zinc monohydrogen phosphate complex in weakly acidic solutions. Electrochimica Acta, Vol. 111, p. 642-655. DOI: 10.1016/j.electacta.2013.07.217.

[20] Biçer, M., Aydın, A.O., Şişman, İ. 2010. Electrochemical synthesis of CdS nanowires by underpotential deposition in anodic alumina membrane templates. Electrochimica Acta, Vol. 55, p. 3749-3755. DOI: 10.1016/j.electacta.2010.02.015.

[21] Innocenti, M., Cinotti, S., Bencista, I., Carretti, E., Becucci, L., Di Benedetto, F., Lavacchi, A., Foresti, M.L. 2014. Electrochemical Growth of $\mathrm{Cu}-\mathrm{Zn}$ Sulfides of Various Stoichiometries. Journal of The Electrochemical Society, Vol. 161, p. D14-D17. DOI: 10.1149/2.021401jes.

[22] Rusi, M.S.R. 2016. Effects of Electrodeposition Mode and Deposition Cycle on the Electrochemical Performance of $\mathrm{MnO}_{2}-\mathrm{NiO}$ Composite Electrodes for High-Energy-Density Supercapacitors. Plos One, Vol. 11, p. e0154566. DOI: 10.1371/journal.pone.0154566.

[23] Palomar Pardave, M., Aldane Gonzalez, J., Botello, L.E., Arce Estrada, E.M., Ramirez Silva, M.T., Mostany, J., Romero Romo, M. 2017. Influence of Temperature on the Thermodynamics and Kinetics of Cobalt Electrochemical Nucleation and Growth. Electrochimica Acta, Vol. 241, p. 162-169. DOI: 10.1016/j.electacta.2017.04.126.

[24] Cheng, S., Chen, G., Chen, Y., Huang, C. 2006. Effect of deposition potential and bath temperature on the 
DEÜ FMD 22(66), 769-779, 2020

electrodeposition of SnS film. Optical Materials, Vol. 29, p. 439-444. DOI: 10.1016/j.optmat.2005.10.018.

[25] Tylka, M.M., Willit, J.L., Williamson, M.A. 2017. Electrochemical Nucleation and Growth of Uranium and Plutonium from Molten Salts. Journal of The Electrochemical Society, Vol. 164, p. H5327-H5335. DOI: $10.1149 / 2.0471708$ jes.

[26] Garfias-Garcia, E., Palamor-Pardave, M., RomeroRomo, M., Ramirez-Silva, M.T., Batina, N. 2007. Kinetic Mechanism of Copper UPD Nucleation and Growth on Mono and Polycrystalline Gold. ECS Transactions, Vol. 3, p. 35-43. DOI: 10.1149/1.2795610.

[27] Cottrell, F.G. 1902. Der reststrom bei galvanischer polarisation, betrachtet als ein diffusionsproblem. Zeitschrift für Physikalische Chemie, Vol. 42, p. 385431. DOI: $10.1515 /$ zpch-1903-4229.

[28] Dogel, J. 2004. Electrochemical SPM Study of 2D and 3D Phase Formation of $\mathrm{Zn}$ at the Ionic Liquid /Au(111) Interface. Universitätsverlag Karlsruhe, Karlsruhe. 